\title{
Onion Cultivation under Low Cost Low Plastic Tunnels for Restricting Over Winter in Eastern Himalayan Region
}

\author{
Moirangthem Sanju Singh ${ }^{1 *}$, Deepak Jhajharia ${ }^{1}$, Khwairakpam Lily Devi ${ }^{1}$, \\ Sapam Rajesh Kumar ${ }^{2}$, Ayam Pushparani Devi ${ }^{3}$ and R. Abdul Fiyaz ${ }^{4}$ \\ ${ }^{1}$ College of Agricultural Engineering and Post Harvest Technology, CAU, \\ Ranipool, Gangtok, Sikkim, 737135 India \\ ${ }^{2}$ College of Horticulture, Bermiok, Gangtok, Sikkim, India \\ ${ }^{3}$ Krishi Vigyan Kendra, Sipahijala, Agartala, Tripura, 799102 India \\ ${ }^{4}$ ICAR-Indian Institute of Rice Research, Rajendranagar, Hyderabad - 500 030, India
}

*Corresponding author

\section{A B S T R A C T}

The present investigation was undertaken to grow vegetable crops during extreme winter condition in north Sikkim condition where snowfall is the biggest problem in vegetable production. Very little research scientific cultivation of vegetable has been conducted in

\section{Keywords}

Tunnel Height, Onion varieties, Microclimate, Overwinter

\section{Article Info}

Accepted:

10 July 2020

Available Online:

10 August 2020 the past and until now scientific production of vegetable is not available. By keeping the above point, an experiment was conducted during 2017-18 and 2018-19 to study the effect of onion cultivation under plastic low cost low tunnels for restricting over winter in eastern Himalayan region at farm of College of Agricultural Engineering and Post-Harvest Technology, Ranipool, Sikkim. The experiment was laid in factorial randomized block design with 10 treatments in three replications. The treatments comprised the three different height of low tunnel i.e., $70 \mathrm{~cm}\left(\mathrm{H}_{1}\right) ; 85 \mathrm{~cm}\left(\mathrm{H}_{2}\right) \& 100 \mathrm{~cm}\left(\mathrm{H}_{3}\right)$, Four varieties of onion i.e F1 hybrid "Rani" - $\mathrm{V}_{1}$, , Nasik red - $\mathrm{V}_{2}$, "Minar" -V3, Leader $-\mathrm{V}_{4}$ and control (open) condition V1, V2, V3, V4. The results revealed that the growth parameter and yield attributing characters were significantly influenced by different low cost low tunnel height and onion varieties. It was seen that interaction of $100 \mathrm{~cm}$ low tunnel height and the variety "Nasik red" produced comparable height, number of leaves, survival percentage, bulbing percentage and bulb diameter. In case of Days to harvest, minimum was recorded in $100 \mathrm{~cm}$ tunnel height and the variety "minar". Among all the treatment, $100 \mathrm{~cm}$ tunnel height with an onion variety "Nasik Red" showed better performance for all the parameter studied and can be considered basis for studying the effect of other agronomic practices.

\section{Introduction}

The present investigation was undertaken to grow vegetable crops during extreme winter condition in north Sikkim condition where snowfall is the biggest problem in vegetable production. India is the second largest onion growing country in the world. Typically, onions are a spring-planted crop, sown for harvest in late summer and kept through as 
much of the winter as possible. Typically, onions are a spring-planted crop, sown for harvest in late summer and kept through as much of the winter as possible. But even with good, cool, dry storage conditions, winter onions eventually turn dark in the center and send out long, green shoots, and there's a long wait before the next year's harvest. The best way to bridge the onion gap is to plant them now for overwintering by using low cost plastic low tunnel. Low tunnels are miniature structures producing green-house like effect in which plastic sheets are used for roof covering of the tunnel with shaped construction having low height, which is built with steel bars. These tunnels facilitate the entrapment of carbon dioxide, thereby enhancing the photosynthetic activity of the plants and hence the yield. These structures also protect the plants from the high winds, rain, frost and snow. Besides being inexpensive, they are easy to construct and dismantle. Low tunnels are being used for producing high quality, high valued nurseries and crops such as tomatoes, cucumber, radish, beans and capsicum (Lodhi et al, 2015). Similarly, Monteiro et al., 2002 also reported that the production obtained under protected condition was higher and of better quality. Saini and Singh, 2006 was reported that there was no significant effect on the yield of chili under low tunnel polyhouse due to variation in perforations on polythene cover. Similar finding was also reported by Arin and Ankara, 2001 to determine the effects of low tunnel, mulching and pruning on yield and earliness of tomato in unheated glass house and showed that there was an increase of $643.42 \%$ in height (relative to height at the planting time) of the plants grown under low tunnel than those grown without tunnel $(602.87 \%)$. The idea of using low tunnels was particularly appealing because in late winter and early spring it is a difficult time to find local food in the Eastern Himalayan region. Keeping in view, this experiment was undertaken to study the effect of Onion cultivation under low cost low plastic tunnels for restricting over winter in eastern Himalayan region.

\section{Materials and Methods}

An experiment was conducted for two consecutive years during October to June, 2017 and 2018 at All India Coordinated Research Project on Plasticulture Engineering and Technologies (AICRP-PET )experimental field of College of Agricultural Engineering and Post-Harvest Technology (CAEPHT), Central Agricultural University (CAU), Ranipool, Sikkim, India to study the Onion cultivation under low cost low plastic tunnels for restricting over winter in eastern Himalayan region on growth, yield and survival percentage of onion under low cost low plastic tunnel in Sikkim condition. The experiment comprised of 10 treatments [viz.T1: $75 \mathrm{~cm}$ Tunnel height, T2: $90 \mathrm{~cm}$ Tunnel height, T3: $100 \mathrm{~cm}$ Tunnel height, T4: onion variety F1 hubrid "Rani", T5: onion variety "Nasik red", T6: onion variety "Minar", T7: onion variety "F1 hubrid "Rani" (control), T8: "Nasik red" (control), T9: "Minar" (control )and T10: "Leader" (control) with three replications following Factorial Randomized Block Design (FRBD).

The site is located in East Sikkim District, Sikkim, India, at $27^{\circ} 17.454^{\prime}$ to $27^{\circ} 17.508^{\prime} \mathrm{N}$ latitude and $88^{\circ} 35.595^{\prime}$ to $88^{\circ} 35.635^{\prime} \mathrm{E}$. The mean maximum and a minimum temperature range from 26 to $36^{\circ} \mathrm{C}$ and 9.4 to $25.4^{\circ} \mathrm{C}$ respectively, with humidity ranging from 60 to $97 \%$ and 24 to $82 \%$, respectively. The soil has a textural composition of sand, silt, and clay as $62 \%, 23 \%$, and $15 \%$ respectively. The available moisture content of the soil (AWC) is $15 \%$ by weight. The soils of Sikkim are generally acidic, $\mathrm{pH}$ ranging from 4.3 to 6.4 with mean value of 5.37. The soil texture is silty to clay loam with depth varying from a 
few inches to several feet. Organic matter content is high with a mean value of $2.74 \%$. The microclimate data during the period of experimentation are presented in Fig. 1.

Onions seeds were obtained from reliable seed distributer from Siliguri, West Bengal. In the nursery bed, seedling was raised under the plastic and 40-45 days old seedling were selected and transplanted in individual plots of $15 \mathrm{~cm}$ raised beds having a dimension of 1 $\mathrm{m}$ width and $3 \mathrm{~m}$ long bed with a spacing of $10 \times 30 \mathrm{~cm}$. The beds were covered with three different low tunnels height, consisting of metal conduit hoops that were placed $1 \mathrm{~m}$ apart. The tunnels were then covered with 6 mil GH plastic on November 17. The tunnels were left undisturbed until the bulb developmental stage. After three months of transplanting, the plastic covers of low tunnels were removed for initiation of bulb formation in onion. Digital thermometer was placed at the individual treatment to record the microclimate parameters for three months from the date of transplanting. After three months of transplanting, the plastic covers of low tunnels were removed for initiation of bulb formation in onion.

Statistical analysis was performed with SAS version 9.2 (SAS, 2010, SAS Institute Inc., Cary, NC, USA). SAS's PROC GLM procedure was used to conduct Analysis of Variance (ANOVA) to know the individual effects of tunnel height and onion varieties and also interaction on growth characteristics, survival percentage and yield component of onion varieties. Furthermore, multiple means comparison was completed for significant $(\mathrm{P}<0.05)$ comparing the least square means of the corresponding treatment combinations.

\section{Results and Discussion}

As per the result shown in table 1, the two factors significantly affected the response measurements either individually (main effects) or jointly (interaction effects). Tunnel height affected days to harvest, fresh weight, yield per hectare, survival percentage, bulbing percentage and bulb diameter; onion varieties affected to plant height, number of leaves, days to harvest, fresh weight, yield per hectare, survival percentage, bulbing percentage and bulb diameter; the interaction affect plant height, days to harvest, yield per hectare, survival percentage, bulbing percentage and bulb diameter.

\section{Effect of growth attributing characteristics, yield attributing character and survival percentage}

Critical observation of plant height revealed significantly different result in respect to microclimate changes in different low tunnel heights and varieties. It was seen that the variety 'Nasik Red' $(37.85 \mathrm{~cm})$ produced the highest plant height which was at par with F1 hybrid Rani (37.40). However, there was no significant difference for plant height among the tunnel heights (table 1). Higher air temperature was observed in this experiment inside the low cost low plastic tunnel relative to control as open condition which encouraged vegetative growth and development at the beginning initial stage of the crop (Fig 1, table1). Result also shows that there was a significant difference for number of leaves on onion varieties. However, number of leaves was not affected by tunnel heights. The maximum number of leaves (5.17) was recorded in the variety "Nasik red" which was at par with 'leader' (4.92 )and the minimum (2.75) was recorded in the variety "F1 hybrid Rani" (Table 1).

Minimum days to harvest (105.41) were recorded in $100 \mathrm{~cm}$ low tunnel height which was significantly higher as compared to lower tunnel height. Minimum days to harvest were significantly showing differences to varieties. 
Table.1 Analysis of variance (ANOVA), F value, P values and effect of low tunnel height, variety and interaction effects (low tunnel height $\mathrm{x}$ variety) on different plant characters on growth and yield characteristics of onion

\begin{tabular}{|c|c|c|c|c|c|c|c|c|c|}
\hline Tunnel Height & Variety & PH & NL & DTH & FW & YPH(T) & SP & BuP & BD \\
\hline H1 & V1 & 43.00 & 2.663 & 114.33 & 22.667 & 7.01 & 19.477 & 20.483 & 1.267 \\
\hline H1 & $\mathrm{V} 2$ & 32.70 & 5.333 & 116.33 & 17.807 & 12.07 & 33.297 & 37.880 & 3.000 \\
\hline H1 & V3 & 24.30 & 2.663 & 106 & 24.667 & 4.08 & 12.113 & 13.043 & 1.467 \\
\hline H1 & V4 & 24.10 & 4.667 & 107 & 15.227 & 3.78 & 30.587 & 32.320 & 2.867 \\
\hline H2 & V1 & 27.1 & 2.330 & 118.66 & 25.333 & 20.30 & 12.983 & 13.110 & 1.467 \\
\hline H2 & $\mathrm{V} 2$ & 36.0 & 5.333 & 119 & 19.837 & 11.29 & 34.727 & 53.993 & 3.767 \\
\hline H2 & V3 & 21.60 & 3.110 & 102.66 & 41.667 & 5.10 & 31.163 & 30.590 & 2.800 \\
\hline H2 & V4 & 23.60 & 4.333 & 104.33 & 19.760 & 6.30 & 31.160 & 44.410 & 3.500 \\
\hline H3 & V1 & 47.00 & 2.887 & 113.66 & 29.667 & 20.02 & 41.120 & 41.700 & 2.267 \\
\hline H3 & $\mathrm{V} 2$ & 48.70 & 5.000 & 97.66 & 32.227 & 21.65 & 65.673 & 66.497 & 3.933 \\
\hline H3 & V3 & 25.20 & 3.220 & 103.66 & 44.333 & 6.67 & 31.160 & 33.443 & 2.767 \\
\hline H3 & V4 & 21.60 & 6.333 & 107.33 & 26.593 & 7.11 & 53.943 & 80.467 & 3.667 \\
\hline Control & V1 & 32.5 & 3.107 & 117.33 & 34.667 & 20.61 & 35.373 & 36.073 & 3.133 \\
\hline Control & V2 & 34.00 & 5.000 & 117.66 & 37.373 & 19.67 & 38.050 & 35.177 & 4.500 \\
\hline Control & V3 & 28.5 & 2.887 & 109.33 & 35.667 & 7.76 & 27.143 & 26.323 & 3.567 \\
\hline Control & V4 & 19.4 & 4.333 & 106.66 & 34.140 & 9.63 & 11.553 & 07.267 & 4.167 \\
\hline \multirow[t]{2}{*}{ Tunnel Height } & F Value & 11.545 & 4.432 & 657.74 & 64.68 & 221.281 & 45.491 & 2.348 & 98.067 \\
\hline & $\mathrm{P}$ value & 0.0071 & 0.0581 & 0.0001 & 0.0001 & 0.0001 & 0.0001 & 0.1720 & 0.0001 \\
\hline \multirow[t]{2}{*}{ Variety } & F value & 79.925 & 73.735 & 59.86 & 53.91 & 362.028 & 346.378 & 1.897 & 200.963 \\
\hline & $\mathrm{P}$ value & 0.0001 & 0.0001 & 0.0001 & 0.0001 & 0.0001 & 0.0001 & 0.1570 & 0.0001 \\
\hline \multirow{2}{*}{$\begin{array}{l}\text { Tunnel Height } \\
\text { X Variety }\end{array}$} & F value & 7.394 & 3.146 & 93.350 & 2.860 & 26.027 & 24.114 & 1.113 & 4.901 \\
\hline & $\mathrm{P}$ value & 0.0001 & 0.0121 & 0.0001 & 0.0191 & 0.0001 & 0.0011 & 0.3910 & 0.0011 \\
\hline
\end{tabular}

Fig.1 Microclimate data under the different tunnel height and control condition during experiment

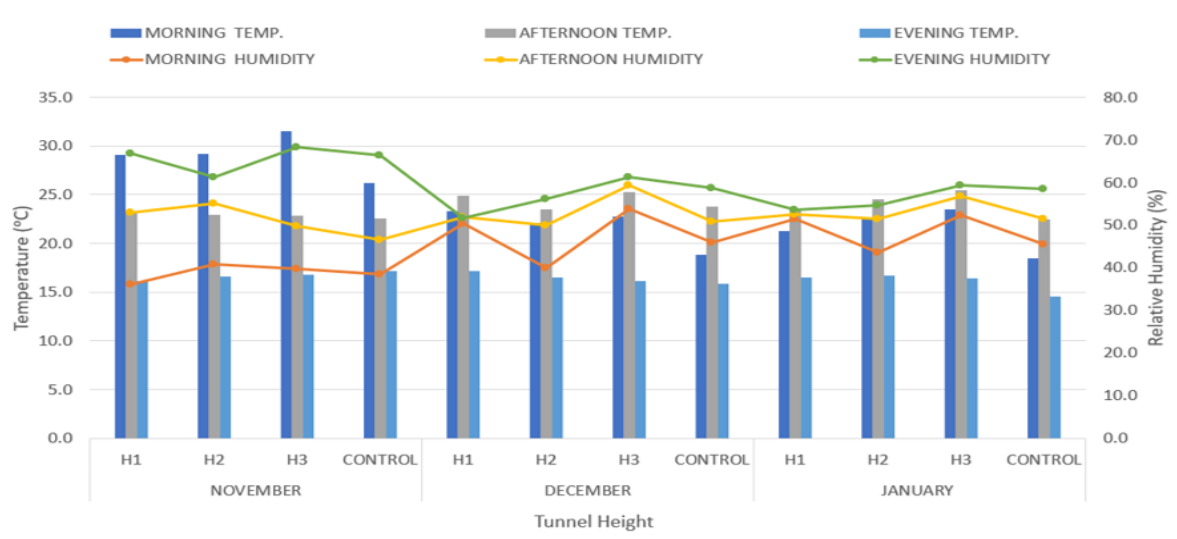


Fig.2 Microclimate data under the different tunnel height and control condition during experiment

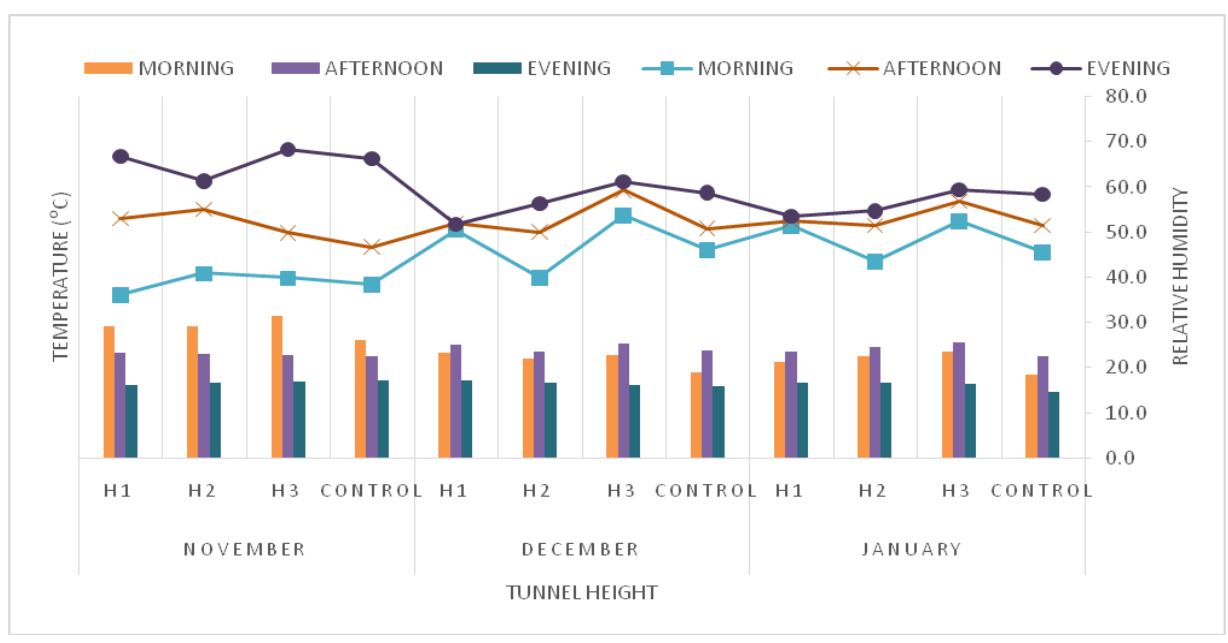

Fig.3 Diffogram showing significant differences between the tunnel heights and onion varieties. The small line passing through the square diagonally represents no significant or significant differences between the corresponding interactions of Tunnel heights and onion varieties

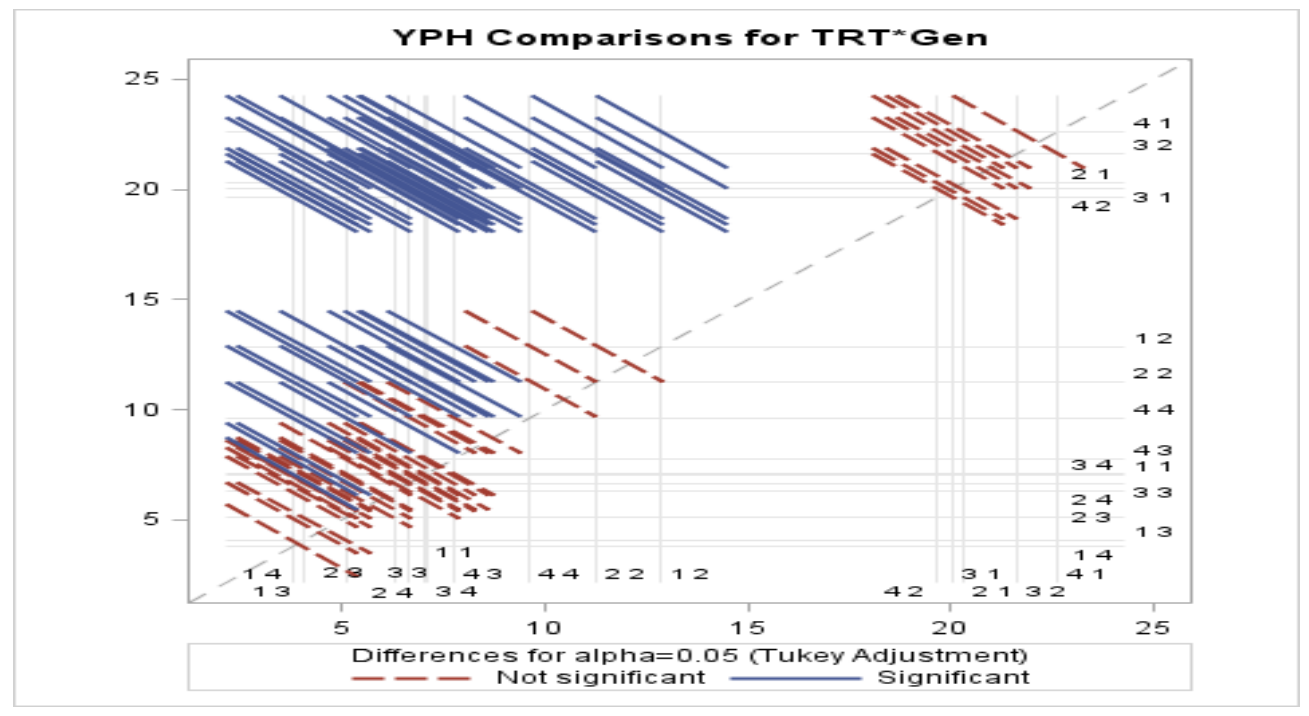

Minimum days to harvest (105.41) was recorded in the variety "Minar" and maximum days to harvest was recorded in the variety F1 hybrid Rani. Similarly, significantly higher values for fresh weight (33.21 g), yield per hectare (13.86), Survival percentage (47.97) and Bulb diameter (3.84 $\mathrm{cm}$ )were also recorded at $100 \mathrm{~cm}$ low tunnel height and minimum of fresh weight (20.09 g), yield per hectare (6.74), Survival percentage (23.87) and Bulb diameter (2.15 $\mathrm{cm})$ at $75 \mathrm{~cm}$ low tunnel height. Bulbing percentage was not significantly affected by tunnel height. Result also shows that there was a significant difference for fresh weight, yield per hectare, Survival percentage and Bulb diameter. Maximum fresh weight (36.58 g) was recorded in the variety "Minar" and minimum was recorded in the variety leader $(23.93 \mathrm{~g})$. similarly maximum yield (16.99 t) was recorded in the variety F1 hybrid "Rani" which was at par with the variety "Nasik red" (16.17) and minimum yield was at the variety "Minar" (5.90 t). However, the maximum 
survival percentage (42.94 \%) and bulb diameter $(3.80 \mathrm{~cm})$ was recorded in the variety "Nasik red" and minimum survival percentage (25.39) at the variety "Minar" and bulb diameter $(2.03 \mathrm{~cm}$ )at F1 hybrid "Rani".

\section{Interaction effect}

The interaction effect of low tunnel tunnel heights and varieties were found to be significant. The maximum plant height was observed in the main interaction of effect of $100 \mathrm{~cm}$ tunnel height and onion variety "Nasik red" (48.70 cm) which was at par with $100 \mathrm{~cm}$ tunnel height and F1 hybrid "Rani" $(47.00 \mathrm{~cm})$ and minimum plant height $(19.40$ $\mathrm{cm})$ was observed in the variety "Leader" $(19.4 \mathrm{~cm})$ as control (open) condition. Maximum number of days to harvest (123.66 ) was recorded in the main interaction of effect of $90 \mathrm{~cm}$ tunnel height and the variety F1 hubrid "Rani" and minimum (97.66 )was recorded in $100 \mathrm{~cm}$ tunnel height and onion variety "Nasik red". Yield per hectare (21.65 t) and survival percentage $(65.67 \%)$ was recorded as highest in the interaction effect of $100 \mathrm{~cm}$ tunnel height and "Nasik Red" and the minimum Yield per hectare $(3.78 \mathrm{t})$ in $75 \mathrm{~cm}$ tunnel height and the variety "Leader" and minimum survival percentage $(11.55 \%)$ was recorded in variety "Leader" which was grown as control (open) condition. The maximum bulb diameter was recorded in the variety "Nasik red" which was grown in open condition and the minimum was recorded in the main interaction of $75 \mathrm{~cm}$ tunnel height and the variety hybrid "Rani". Significant differences between treatment interaction were graphically represented by diffogram using PROC GLM SAS (SAS Institute, Version 9.2) (Fig 2).

The present investigation shows that the increase in plant height was observed in the tunnel height over open condition due to increase in temperature inside the low tunnel. Higher air temperature was observed in this experiment inside the low cost low plastic tunnel relative to control as open condition which encouraged vegetative growth and development at the beginning initial stage of the crop. The same result shows the increases in height and stem diameter of the crops grown under tunnel and mulched have been found much more than control plants (Levent and Sözer, 2001). Tressen (1983) also reported that critical soil temperature is $14^{\circ} \mathrm{C}$ for tomatoes and the development stops or becomes slowly below this temperature. Gerber et al., (1988) reported that the pepper crop development increases by the increases of soil temperature due to tunnel effect. The results are in accordance with the findings of Pimpini et al., (1987) who have observed that low tunnel and transparent polyethylene mulch increases the earliness in two tomato varieties. Tressen (1983) also recorded earliness and more yield with the $1-2{ }^{\circ} \mathrm{C}$ increase in temperature by the use of mulch. Yield per hectare, survival percentage, bulbing percentage and buld diameter was recorded as highest in the interaction effect of $100 \mathrm{~cm}$ tunnel height and Nasik Red which were due to increases the net photosynthesis and production of more assimilates available for individual to grow. Vegetative growth was greatest in plants in the tunnel where the thermal condition were best early and total marketable yield were highest under the poly tunnel (Ashish et al., 2019).

The necessity for adoption of novel vegetable growing in low cost low plastic tunnel during snowfall condition in north Sikkim during October to April month of the year has been the most important issue in the present agricultural production systems. The main challenge is to grow the vegetable crops by use of low cost low plastic tunnel. Low tunnel facilitate the entrapment of carbon dioxide, thereby enhancing the photosynthetic activity of the plants and hence the yield. These structures also protect the plants from the high winds, rain, frost and snow. Besides being 
inexpensive, they are easy to construct and dismantle. Low tunnels are being used for producing high quality, high valued nurseries and crops such as tomatoes, cucumber, radish, beans and capsicum (Lodhi et al., 2015). Monteiro et al., 2002 also carried out a study on perforated plastic film for low tunnels cultivated with lettuce without lettuce, with 0 , $5,10,15$ and $20 \%$ of perforated film area and in soil without tunnel. In conclusion, the present study can state that onion variety Nasik Red can raised in low cost low plastic tunnel height of $100 \mathrm{~cm}$ for restricting overwinter in Sikkim condition.

\section{Acknowledgement}

The authors gratefully acknowledge the financial support received from the Project Coordinating Unit, AICRP on Plasticulture Engineering \& Technology (Indian Council of Agricultural Research under Ministry of Agriculture \& Farmers Welfare, Govt. of India), Central Institute of Post Harvest Engineering \& Technology, Ludhiana, Punjab for successful completion of the approved research project "Onion cultivation under low tunnels for restricting over winter in eastern Himalayan region" during the XII ${ }^{\text {th }}$ Workshop of AICRP-PET held from 15-16 December 2016 at MPUAT (Udaipur), Rajasthan.

\section{References}

Arin L, Ankara S. 2001. Effect of low tunnel, mulch and pruning on the yield and earliness to tomato in unheated green house. J App Hort. 3: 23-27.

Ashish R, Anand K, Suraj P, Awadhesh KP. 2019.
Effect of Low Poly Tunnel and Planting time on Growth Parameters and Yield of Muskmelon. Int J Cur Microb App Sci. 8: 2735-2739.

Gerber J M, Mohd-Khir I, Splittoesser WE.1988. Row Tunnel Effects on Growth, Yield and Fruit Quality of Bell Pepper. Hort Sci. 26:191-197.

Levent A, Ankara S. 2001. Effect of low-tunnel, mulch and pruning on the yieldand earliness of tomato in unheated glasshouse. J App Hort. 3:23-27.

Lodhi A S, Arun K, Kamal G S. 2015. Low tunnel technology for vegetable production in India.

Monteiro JEBA, Silva IJO, Piedade SM. 2002. Perforated plastic film for low tunnels cultivated with lettuce. RevistaBrasileira-deEngenharia Agricola -Ambiental. 6: 535538.

Pimpini F, Granguinto G, Babbo G, Xodo E. 1987. The Effect of Protective Structures and of Pinching on the Earliness of TableTomatoes in the Greenhouse. Prottte. 16:63-73.

Saini A K, Singh K G. 2001. In: Annual report of All India Coordinated Research, Project on application of plastics in agriculture. pp. 6974. Dep. Soil Water Engg., Punjab Agricultural University, Ludhiana, India, 2001

Shiraiwa N, Kashima Y, Itai A, Tanabe K. 2007. Effects of tunnel covering plastic films and fertilization methods on growth, bolting and yield in Welsh onion (Allium fistulosum L. )harvested in early summer. Hort Res. 6: 17.

Singh R, Asrey R, Kumar S. 2006. Effect of plastic tunnel and mulching on growth and yield of strawberry. Ind J Hort. 63: 18-20.

Tressen T. 1983. Polyethylene Mulches in Vegetable Production. Order No. 78-008, Ontario, 4 p. 1983.

\section{How to cite this article:}

Moirangthem Sanju Singh, Deepak Jhajharia, Khwairakpam Lily Devi, Sapam Rajesh Kumar, Ayam Pushparani Devi and Abdul Fiyaz, R. 2020. Onion Cultivation under Low Cost Low Plastic Tunnels for Restricting Over Winter in Eastern Himalayan Region. Int.J.Curr.Microbiol.App.Sci. 9(08): 650-657. doi: https://doi.org/10.20546/ijcmas.2020.908.072 